\title{
The Burden of Rheumatoid Arthritis in Spain
}

\author{
Paula Andrade ${ }^{1 *}$, Jose A Sacristan ${ }^{1}$, Maria Luz Rentero ${ }^{1}$, Volker Hammen ${ }^{2}$ and Tatiana Dilla ${ }^{1}$ \\ ${ }^{1}$ Lilly Espana, Avenida de la Industria, 28108 Alcobendas, Madrid, Spain \\ 'Lilly Deutschland GmbH, Werner-Reimers-Straße 2-4, 61352 Bad Homburg, Germany
}

\begin{abstract}
Introduction: Rheumatoid arthritis (RA) is a chronic inflammatory disease with an estimated prevalence of 0.2 $1.1 \%$. Fatigue, swelling and deformation of the joints are complications of RA that lead to physical dysfunction and a considerable economic burden. The objective of this review was to bring together and analyze the Spanish publications on the burden of RA in Spain in terms of frequency, associated comorbidities, impact on quality of life, and associated costs.
\end{abstract}

Methods: A search was conducted in MEDLINE, EMBASE (2000 to 2014), and in the reference lists of previous reviews. We identified 18 publications of interest in the Spanish setting.

Results: After an analysis of the literature, we found that RA in Spain has a prevalence of $0.50 \%$ and an incidence of 0.08 to 0.20 cases $/ 1000$ person-years. The most common comorbidities associated with RA are dyslipidemia, hypertension, depression and diabetes. In addition, RA is associated with an excess mortality of $85 \%$ compared to the general population. With regard to quality of life, RA has a significant negative effect on its physical component. Economic studies showed that the annual cost per patient varies depending on the study ( $€ 3,600$ to $€ 11,707$ in 2002). The largest component of RA annual cost is direct costs, representing $70-75 \%$ of the total.

Conclusion: RA in Spain is associated with impaired quality of life, increased disability and costs, and increased mortality. Epidemiological data indicate that the frequency of RA in Spain is similar to that of other developed countries.

Keywords: Cost-of-illness; Cancer; Economic burden; Systematic review; Oncology

\section{Introduction}

According to a systematic review of studies in adults, the prevalence of Rheumatoid Arthritis (RA) is $0.2-1.1 \%$ in developed countries, is higher in women, and has a large geographical variation [1]. The incidence of the disease varies, depending on country, from 0.1 to 0.5 patients per 1000 inhabitants [1]. RA is associated with frequent comorbid conditions, especially cardiovascular diseases, gastrointestinal disorders, infections, psychiatric disorders and, more infrequently, some malignancies [2]. Importantly, RA is associated with an excess mortality of over $40 \%$ compared with the general population $[3,4]$.

Health-Related Quality of Life (HRQoL) is also lower in patients with RA than in those with other disorders. This was shown in a metaanalysis of 31 studies, involving 22,335 patients, that compared HRQoL [using the 36-item Short-Form Health Survey (SF-36)] in patients with RA with matched HRQoL data for patients with hypertension, type 2 diabetes, myocardial infarction, or depression [5].

RA also carries a significant economic burden. A large multinational study (involving 32 countries including Spain) in patients with RA aged $<65$ years who were still working at the onset of symptoms showed that $37 \%$ subsequently became work-disabled because of disease progression (median 9 years) [6]. The total national annual cost of RA has been estimated at $€ 45.3$ billion in Europe and at $€ 41.6$ billion in the USA (2006 values); the total annual cost of RA per patient has been estimated at $€ 13,463$ in Europe and $€ 21,069$ in the USA.7 In Europe, medical costs and drugs accounted for $35 \%$ of the cost, and nonmedical costs for $14 \%$ [7].

This review summarizes the published literature on the burden of RA in Spain in terms of frequency, comorbidity and mortality, impact on quality of life, and associated costs.

\section{Literature Search}

We searched PubMed and EMBASE from December 2000 to December 2014 using the following terms: [Rheumatoid Arthritis and (Spain or Espana) and (economic or economics or pharmacoeconomic or pharmacoeconomics or cost or costs or price or pricing or expenditure or burden or "Quality of life")] or [Rheumatoid Arthritis and (Spain or Espana) and (incidence or prevalence)] or [Rheumatoid Arthritis and (Spain or Espana) and (anxiety or depression or "depressive illness" or mortality or suicide or worry or distress or psychosis or neurosis)]. Additionally, we searched the reference lists of those articles identified by the original search and of those from selected reviews on the topic for further publications of interest. We focused on original articles and excluded articles related to the analysis of specific pharmacologic interventions, cost-effectiveness studies, and studies only in abstract and/or poster form.

The literature search returned 15 articles [8-22], and the review of the reference lists of these articles and reviews on the topic provided three additional references [23-25], leading to a total of 18 publications that have been included in this review: prevalence and incidence (three publications), comorbidity and mortality (seven), quality of life (five), and costs (three).

*Corresponding author: Paula Andrade, Lilly Espana, Avenida de la Industria, 30, 28108 Alcobendas, Madrid, Spain, Tel: +34 916635334; Fax: +34916233316; E-mail: andrade_paula@lilly.com

Received December 16, 2016; Accepted February 01, 2017; Published February 07, 2017

Citation: Andrade P, Sacristan JA, Rentero ML, Hammen V, Dilla T (2017) The Burden of Rheumatoid Arthritis in Spain. Health Econ Outcome Res Open Access 3: 126. doi: 10.4172/2471-268x/1000126

Copyright: (c) 2017 Andrade P, et al. This is an open-access article distributed under the terms of the Creative Commons Attribution License, which permits unrestricted use, distribution, and reproduction in any medium, provided the original author and source are credited. 


\section{Prevalence and incidence}

In the three studies reporting the prevalence and/or incidence of RA in Spain [6-8], results were similar to those of other comparable countries or regions [1].

The EPISER study evaluated the prevalence of musculoskeletal disorders in Spain and randomly selected 2998 adults from the censuses of 20 cities [8]. Diagnostic assessment using the 1987 American College of Rheumatology (ACR) criteria was possible in 2192 subjects. The authors identified 11 patients (nine women and two men) with RA and reported a prevalence of $0.5 \%$ (95\% confidence interval [CI]: 0.25 to $0.85)$; prevalence was higher in women than in men $(0.8 \%$ [95\% CI: 0.4 to 1.1 ] and $0.2 \%$ [ $95 \% \mathrm{CI}:<0.5$ ], respectively) [9]. Extrapolating the data to a population of around 40 million, they estimated that there were $150,000-200,000$ cases of RA in Spain. A population-based study was carried out in Catalonia (Eastern Spain) using a primary care database (SIDIAP [Information System for the Development of Research at Primary Care]) that included data from about 5.4 million people aged 14 years or older and a follow-up period of 4 years for the incidence calculation (see next paragraph) [10]. In the evaluable patients $(n=4,895,307)$, these authors reported an age- and sex-standardized prevalence of RA (International Classification of Diseases [ICD-10] codes M05 and M06) slightly lower (0.42\% [95\% CI: 0.41 to 0.42$]$ ) than the overall prevalence in the EPISER study [8]. The prevalence of RA in the EPISER study and the study conducted in Catalonia is within the range reported for developed countries $(0.2-1.1 \%)$ in a systematic review of the epidemiology of RA [1]. Results were also consistent with those reported in south European countries (range 0.31-0.50\%), which were lower than those reported in north European countries (0.44$0.80 \%)$ or the USA $(1.07 \%)$ [1].

The incidence of RA in Spain has been estimated in two studies $[9,10]$. Carbonell et al. conducted a study in 20 specialized rheumatology units throughout Spain that, over 1 year, recruited patients with suspected early arthritis attending associated primary care centers $(83.4 \%$ of the referrals), other specialists $(9.3 \%)$, and emergency departments (3.4\%).9 From 2467 referrals and a reference population of 4,342,378 adults, 362 patients were diagnosed with RA using the 1987 ACR criteria, giving an estimated annual incidence of RA of 0.08 cases per 1000 person-years in those aged $>16$ years [9]. The incidence was twice as high in females $(0.11$ cases $/ 1000$ inhabitants [95\% CI: 0.10 to 0.13 ]) as in males $(0.05$ cases/1000 inhabitants [ $95 \%$ CI: 0.04 to 0.06$]$ ), and increased with increasing age, showing a peak at $51-60$ years in women $(0.18$ cases $/ 1000$ inhabitants [95\% CI: 0.14 to 0.24$])$ and at $>70$ years in men $(0.16$ cases/ 1000 inhabitants $[95 \%$ CI: 0.12 to 0.22$]$ ). A more recent study using the SIDIAP database, mentioned earlier, reported an age- and sex-standardized incidence of RA (according to ICD-10 codes) of 0.20 per 1000 person-years (95\% CI: 0.19 to 0.20$) ; 10$ the age-standardized incidence was again at least twice as high in females $(0.28 / 1000$ person-years [ $95 \%$ CI: 0.27 to 0.29 ]) as in males $(0.12 / 1000$ person-years [ $95 \%$ CI: 0.11 to 0.12$])$, and increased with age, showing a peak at the age range of 65 to $<70$ years $(0.51 / 1000$ and $0.31 / 1000$ person-years in women and men, respectively). These incidence rates are also within the range for other developed countries (0.1-0.5/1000 inhabitants). 1 Similarly, the predominance of RA in females is consistent with that reported worldwide [1].

\section{Comorbidity and mortality}

The comorbidities present in patients with RA in Spain were described in three studies $[21,24,25]$. Unfortunately, none of these studies included a general population comparison group, and therefore no robust conclusions can be drawn regarding the type or prevalence of comorbidities in patients with RA. In addition, the information on cancer rates is based on a study with small sample size making the findings inconclusive. However, despite these limitations, the information from these studies is contributory.

A list of selected comorbidities was evaluated during a clinical interview and through a review of medical records in a recent crosssectional study (COMORA) of 3920 patients with RA (1987 ACR criteria) consecutively selected by participant rheumatologists in 17 countries [24]. In this study, the prevalence of past or current comorbidities among the 200 patients recruited in Spain was as follows: metabolic: dyslipidemia (46\%) and diabetes (12\%); cardiovascular: hypertension (41\%), myocardial infarction (5\%), and stroke (1\%); psychiatric: depression (27\%); pulmonary: asthma (5\%) and chronic pulmonary obstructive disease (2\%); hepatitis: hepatitis B (5\%) and hepatitis C (1\%); gastrointestinal: ulcers (3\%); and cancers: basal cell carcinoma (3\%), breast cancer $(2 \%)$, uterine cancer $(1 \%)$, colorectal cancer $(1 \%)$, and cutaneous melanoma $(1 \%)$. There were no cases of diverticulitis requiring surgery, prostatic cancer, lung cancer, or lymphoma. In another international, cross-sectional study (QUESTRA), the prevalence of cardiovascular events (i.e., myocardial infarction, angina, coronary heart disease, coronary bypass surgery, or stroke) was 10\% among 301 Spanish patients with RA (1987 ACR criteria); results by country are provided in aggregate form only [25]. Hypertension $(28 \%)$ and diabetes $(10 \%)$ were the most frequent comorbidities in 1272 patients with RA randomly selected at rheumatology departments of hospitals throughout Spain in the third study [21]. Overall, these studies show that the most frequent comorbidities include dyslipidemia, hypertension, and diabetes, which are well-known risk factors for cardiovascular disease [26], a result consistent with earlier findings [2]

The studies reporting mortality data from patients with RA in Spain are summarized in Table 1. One study reporting results for all-cause mortality used data from 182 consecutive patients at a tertiary hospital in central Spain followed for 9 years or until death [23]. Results of this study suggested an $85 \%$ excess mortality compared with the general population, which is higher than the values reported in two systematic reviews that included studies enrolling patients from a number of countries [standardized mortality ratios (SMRs) 1.44 and 1.48] [3,4] SMRs in Spain were higher in males than in females (2.34 and 2.09, respectively; no CIs reported). The most frequent causes of death were cardiovascular disease $(21 \%)$, infection $(21 \%)$, and kidney failure (17.3\%) [23].

In another study, the cardiovascular mortality SMR was 1.78 (CI not provided) in 182 patients with RA from a center in northwestern Spain who were followed for 9-9.5 years or until death [11]. This excess of cardiovascular mortality is consistent with the comorbidity profile previously mentioned.

Two studies have reported that cancer deaths are not increased in Spanish patients with RA (Table 1) $[12,13]$. The cancer SMR in both studies was 1.0. However, in the largest study, mortality was increased for lung adenocarcinoma, with an SMR of 4.5 (95\% CI: 2.1 to 8.5$)$ and renal carcinoma, with an SMR of 8.7 (95\% CI: 1.1 to 31.4) [13].

\section{Impact on quality of life and perception of quality of life}

The five studies reporting results on the Quality of Life (QoL) of patients with RA in Spain are summarized in Table 2. The two studies reporting the impact of RA on quality of life using the SF-36/SF-12 showed an important negative effect on the physical component of 
Citation: Andrade P, Sacristan JA, Rentero ML, Hammen V, Dilla T (2017) The Burden of Rheumatoid Arthritis in Spain. Health Econ Outcome Res Open Access 3: 126. doi: 10.4172/2471-268x/1000126

Page 3 of 6

\begin{tabular}{|c|c|c|c|c|c|c|c|}
\hline \multirow{2}{*}{ Author, year } & \multirow{2}{*}{ Ref. No. } & \multirow{2}{*}{ Study design } & \multirow{2}{*}{ Cause of death } & \multicolumn{3}{|c|}{ Standardized mortality ratio $(95 \% \mathrm{Cl})$} & \multirow{2}{*}{ Other findings } \\
\hline & & & & Overall & Female & Male & \\
\hline $\begin{array}{c}\text { Sanchez Martinez, } \\
2001\end{array}$ & 22 & $\begin{array}{c}182 \text { consecutive patients } \\
>16 \text { years attending a } \\
\text { tertiary care hospital in } \\
\text { the central region of Spain } \\
\text { (Madrid) } \\
\text { Diagnosis: NR } \\
\text { Follow-up: } 9 \text { years starting } \\
\text { from } 1989\end{array}$ & All & 1.85 & 2.09 & 2.34 & $\begin{array}{c}\text { Mortality rate: } 15.4 \\
\text { deaths } / 1000 \text { person-years }\end{array}$ \\
\hline $\begin{array}{c}\text { Gonzalez-Gay, } \\
2007\end{array}$ & 10 & $\begin{array}{c}\text { Prospective cohort of } \\
182 \text { consecutive patients } \\
\text { attending a hospital from } \\
\text { northwestern Spain (Lugo) } \\
\text { Diagnosis: 1987 ACR } \\
\text { criteria } \\
\text { Follow-up: 9-9.5 years } \\
\text { (1996-2005) }\end{array}$ & Cardiovascular & 1.78 & NR & NR & \\
\hline Llorca, 2007 & 11 & $\begin{array}{c}\text { Prospective cohort of } \\
182 \text { consecutive patients } \\
\text { attending a hospital from } \\
\text { northwestern Spain (Lugo) } \\
\text { Diagnosis: } 1987 \text { ACR } \\
\text { criteria } \\
\text { Follow-up: 9-9.5 years } \\
\text { (1996-2005) }\end{array}$ & Cancer & $\begin{array}{c}1.01 \\
(0.49-1.75)\end{array}$ & $\begin{array}{c}0.53 \\
(0.11-1.54)\end{array}$ & $\begin{array}{c}1.67 \\
(0.67-3.44)\end{array}$ & $\begin{array}{c}\text { Cancer mortality rate: } \\
\text { 4.1/1000 person-years }(95 \% \\
\text { Cl } 2.0-7.5)\end{array}$ \\
\hline Abásolo, 2008 & 12 & $\begin{array}{c}\text { Random sample of } 789 \\
\text { patients selected from } 34 \\
\text { centers } \\
\text { Diagnosis: } 1987 \text { ACR } \\
\text { criteria } \\
\text { Follow-up: median } 4 \text { years } \\
\text { (1999-2005) }\end{array}$ & $\begin{array}{c}\text { Cancer (all) } \\
\text { Lung } \\
\text { adenocarcinoma } \\
\text { Renal carcinoma }\end{array}$ & $\begin{array}{c}1.0 \\
(0.5-1.7) \\
4.5 \\
(2.1-8.5) \\
8.7 \\
(1.1-31.4)\end{array}$ & $\begin{array}{c}0.3 \\
(0.04-1.1) \\
- \\
8.9 \\
(0.2-49.3)\end{array}$ & $\begin{array}{c}1.8 \\
(0.9-3.2) \\
5.4 \\
(2.4-10.1) \\
8.5 \\
(0.2-47.5)\end{array}$ & $\begin{array}{c}\text { SIR of cancer }(95 \% \mathrm{Cl}) \text { : } \\
\text { All: } 1.2(0.8-1.8) \\
\text { Lung adenocarcinoma: } 3.5 \\
(1.4-7.1) \\
\text { Leukemia: } 8.8(2.4-22.6) \\
\text { Non-Hodgkin lymphoma } 5.4 \\
\quad(1.1-15.7) \\
\text { Incidence for other cancer } \\
\text { locations not significantly } \\
\text { increased }\end{array}$ \\
\hline
\end{tabular}

Table 1: Mortality studies in patients with rheumatoid arthritis in Spain.

\begin{tabular}{|c|c|c|c|c|c|}
\hline Author, year & Ref. \# & Study design & Outcome measures & Patient characteristics ${ }^{a}$ & Key findings \\
\hline $\begin{array}{c}\text { Navarro Sarabia, } \\
2004\end{array}$ & 18 & $\begin{array}{l}\text { Observational, prospective } \\
\text { cohort study } \\
301 \text { patients with RA (ACR } \\
\text { criteria) were randomly } \\
\text { selected from } 2488 \\
\text { candidates recruited by ten } \\
\text { centers throughout Spain }\end{array}$ & SF-36 & $\begin{array}{c}\text { Age: } 59(13) \text { years } \\
\text { Sex: } 82 \% \text { females } \\
\text { Disease duration: median } \\
10 \text { (IQR } 5-14 \text { ) years } \\
\text { DAS } 28: 4.5(1.5) \\
\text { HAQ: } 1.1 \text { (IQR } 0.3 \text { to } 1.9 \text { ) }\end{array}$ & $\begin{array}{c}\text { Significantly lower scores in all eight } \\
\text { dimensions of the HRQoL in patients with RA } \\
\text { compared with the general population (Note: } \\
\text { main findings of this study are presented in } \\
\text { a figure) } \\
\text { Largest differences were observed for } \\
\text { physical function, and bodily pain, (i.e., } \\
\text { physical component) (scores around } 40 \% \\
\text { below those of the general population) } \\
\text { Women had significantly lower scores } \\
\text { than men in physical function, vitality, role } \\
\text { emotional, and mental health }\end{array}$ \\
\hline Nuñez, 2006 & 14 & $\begin{array}{c}\text { Observational, cross-sectional } \\
\text { study using analysis of textual } \\
\text { data } \\
98 \text { consecutive patients with } \\
\text { RA (1987 ACR criteria) from a } \\
\text { tertiary hospital and a primary } \\
\text { care center in the north of } \\
\text { Spain (Barcelona) }\end{array}$ & Ad hoc questionnaire & $\begin{array}{l}\text { Age: } 58.6(13.0) \text { years } \\
\text { Sex: } 85 \% \text { females } \\
\text { Disease duration: } 144.4 \\
\text { (167) months }\end{array}$ & $\begin{array}{l}\text { Patients with RA tended to focus their } \\
\text { perception of quality of life specifically on } \\
\text { their ability to do things }\end{array}$ \\
\hline Loza, 2008 & 16 & $\begin{array}{l}\text { Random sample of } 2192 \\
\text { subjects (reference } 972,545 ; \\
2998 \text { selected [ } 73 \% \text { response } \\
\text { rate]), >16 years, from the } \\
\text { census of } 20 \text { cities/villages in } \\
\text { Spain, proportional by sex, } \\
\text { age, and rural/urban area to } \\
\text { the Spanish population } \\
0.5 \% \text { diagnosed with RA with } \\
\text { the modified } 1987 \text { ACR criteria } \\
+ \text { RF analysis if required }\end{array}$ & SF-12 & NR & $\begin{array}{l}\text { Results suggested the physical component } \\
\text { of the HRQL is significantly negatively } \\
\text { affected by RA, but the mental component is } \\
\text { positively although not significantly affected } \\
\text { Physical component: } \beta \text { coefficient }-10.5 \\
\text { (95\%Cl: }-17.7 \text { to }-3.29) \\
\text { Mental component: } \beta \text { coefficient } 2.22 \\
(95 \% \mathrm{Cl}:-6.15 \text { to } 10.59) \\
\text { (Multiple linear regression analysis } \\
\text { adjusted for study design, age, sex, place } \\
\text { of residence, education, social class, and } \\
\text { employment status) }\end{array}$ \\
\hline
\end{tabular}




\begin{tabular}{|c|c|c|c|c|c|}
\hline Nuñez, 2009 & 15 & $\begin{array}{c}\text { Observational, cross-sectional } \\
\text { study using analysis of textual } \\
\text { data } \\
781 \text { consecutive patients } \\
\text { with RA ( } 1987 \text { ACR criteria) } \\
\text { from two tertiary hospitals, } \\
\text { six county hospitals, and five } \\
\text { primary care centers in the } \\
\text { north of Spain (Catalonia) }\end{array}$ & Ad hoc questionnaire & $\begin{array}{c}\text { Age: } 60.7(14.2) \text { years } \\
\text { Sex: } 78.8 \% \text { females } \\
\text { Disease duration: } 11.2(9.7) \\
\text { years } \\
\text { DAS 28: } 4.0(1.4)\end{array}$ & $\begin{array}{l}\text { When referring to their HRQoL, patients } \\
\text { used terms that focused mainly on the } \\
\text { functional capacity and pain ("to be able to } \\
\text { do" and "not having any pain") } \\
\text { Sociodemographic variables (age, } \\
\text { education, and economic level) influence the } \\
\text { perception of quality of life }\end{array}$ \\
\hline Carreño, 2011 & 13 & $\begin{array}{l}\text { Observational, cross-sectional } \\
\text { study } \\
14 \text { rheumatologists from } \\
\text { outpatient clinics throughout } \\
\text { Spain recruited } 247 \\
\text { consecutive patients with RA } \\
\text { (1987 ACR criteria) }\end{array}$ & $\begin{array}{l}\text { EQ-VAS } \\
\text { EQ-5D } \\
\text { HUI-3 }\end{array}$ & $\begin{array}{c}\text { Age: } 57.8(13.3) \\
\text { Sex: } 75.8 \% \text { females } \\
\text { Disease duration: } 10.8(9) \\
\text { years } \\
\text { HAQ: } 1.02(0.78)\end{array}$ & $\begin{array}{c}\text { Mean EQ-VAS score: } 63.1(20.3) \\
\text { Mean utility value (EQ-5D): } 0.65(0.3) \\
\text { Mean utility score (HUI-3): } 0.75(0.21) \\
80.4 \% \text { had pain or discomfort } \\
53.2 \% \text { had difficulty performing daily } \\
\text { activities } \\
44.2 \% \text { had mobility problems } \\
39.6 \% \text { experienced anxiety or depression } \\
35.3 \% \text { had problems with self-care } \\
\text { The reported level of problems for all EQ-5Q } \\
\text { dimensions increased as the severity of RA } \\
\text { increased }\end{array}$ \\
\hline \multicolumn{6}{|c|}{$\begin{array}{l}\text { aData are presented as mean (standard deviation) unless otherwise indicated; IQR, interquartile range } \\
\text { ACR: American College of Rheumatology, CI: Confidence Interval, DAS: Disease Activity Score, EQ-5D: EuroQol } 5 \text { Dimensions, EQ-VAS: EuroQol Visual Analog Scale, } \\
\text { HAQ: Health Assessment Questionnaire, HRQoL: Health Related Quality of Life, HUI-3: Health Utility Index Mark 3, IQR: Interquartile Range, NR: Not Reported, RA: } \\
\text { Rheumatoid Arthritis, Ref. \#: Reference Number, RF: Rheumatoid Factor, SF-12 12-item: Short-Form Health Survey, SF-36 36-item: Short-Form Health Survey }\end{array}$} \\
\hline
\end{tabular}

Table 2: Studies on quality of life of patients with rheumatoid arthritis in Spain.

\begin{tabular}{|c|c|c|c|c|c|c|c|}
\hline \multirow{2}{*}{ Author, year } & \multirow{2}{*}{ Ref. \# } & \multirow{2}{*}{ Study design } & \multirow{2}{*}{ Source of data } & \multirow{2}{*}{ Patient characteristics ${ }^{a}$} & \multirow{2}{*}{ Total cost } & \multicolumn{2}{|c|}{ Cost distribution, $\%$} \\
\hline & & & & & & Direct $^{\mathrm{b}}$ & Indirect ${ }^{\mathrm{b}}$ \\
\hline Lajas, 2003 & 17 & $\begin{array}{l}\text { Observational, 12-month } \\
\text { retrospective cohort } \\
\text { study of } 201 \text { patients } \\
\text { with RA (1987 ACR } \\
\text { criteria) randomly } \\
\text { selected from a } \\
\text { rheumatology registry of } \\
\text { a tertiary hospital in the } \\
\text { center of Spain (Madrid) }\end{array}$ & $\begin{array}{l}\text { Medical expenses } \\
\text { of specialized care, } \\
\text { from the registry } \\
\text { Other expenses } \\
\text { from a scheduled } \\
\text { interview }\end{array}$ & $\begin{array}{c}\text { Age: } 64.3 \text { (11.8) years } \\
\text { Sex: } 77.6 \% \text { female } \\
\text { Disease duration: median } \\
7.7 \text { (IQR } 3.3-14.3) \\
\text { HAQ: median 1.025 (IQR } \\
0.37-1.5)\end{array}$ & $\begin{array}{c}\text { Sample: } \begin{array}{c}\$ \text { US2.07 million/ } \\
\text { year }\end{array} \\
\text { Patient: } \$ \text { US10,419/year } \\
\text { (range } \$ 7,914-\$ 12,922 / \\
\text { year) } \\
\text { (year 2001 values) }\end{array}$ & $\begin{array}{c}\text { Total 69.1 } \\
\text { Medical (39.2) } \\
\text { Drugs [24.3] } \\
\text { Surg. ad. [43.9] } \\
\text { Nonmedical (60.7) } \\
\text { Help for patient at } \\
\text { home, work, and } \\
\text { self-care [56.3] }\end{array}$ & $\begin{array}{l}\text { Total } 30.9 \\
\text { Work com. } \\
(64.0) \\
\text { Home help for } \\
\text { carer (36.0) }\end{array}$ \\
\hline $\begin{array}{c}\text { Navarro } \\
\text { Sarabia, } 2004\end{array}$ & 18 & $\begin{array}{l}\text { Observational, 12-month } \\
\text { prospective cohort study } \\
301 \text { patients with RA } \\
\text { (ACR criteria) were } \\
\text { randomly selected } \\
\text { from } 2488 \text { candidates } \\
\text { recruited by ten centers } \\
\text { throughout Spain } \\
\text { Cost analyses included } \\
222 \text { patients who } \\
\text { completed the four study } \\
\text { visits }\end{array}$ & $\begin{array}{l}\text { Medical history, } \\
\text { patients' diary, } \\
\text { scheduled } \\
\text { interview }\end{array}$ & $\begin{array}{c}\text { Age: } 59(13) \text { years } \\
\text { Sex: } 82 \% \text { female } \\
\text { Disease duration: median } \\
10 \text { (IQR 5-14) years } \\
\text { DAS 28: } 4.5(1.5) \\
\text { HAQ: median 1.1 (IQR } \\
0.3-1.9)\end{array}$ & $\begin{array}{c}\text { Sample: } € 1,168,410 \\
\text { Patient: median } € 3600 / \\
\text { year (range } € 119- \\
€ 29,767 \text { ) } \\
\text { Spain (total annual costs } \\
\text { for } 200,000 \text { patients): } \\
€ 1120 \text { million } \\
\text { (year } 2002 \text { values) }\end{array}$ & $\begin{array}{c}\text { Total 75.3 } \\
\text { Medical (80.4) } \\
\text { Drugs [56.8] } \\
\text { Visits [22.0] } \\
\text { Hosp. ad. [9.2] } \\
\text { Nonmedical (19.6) }\end{array}$ & $\begin{array}{c}\text { Total } 24.7 \\
P W D(74.5) \\
T W D(25.5)\end{array}$ \\
\hline $\begin{array}{c}\text { Mera Varela } \\
2003\end{array}$ & 21 & \begin{tabular}{|} 
Observational, \\
prospective cohort study \\
150 consecutive patients \\
with RA (1987 ACR \\
criteria) recruited in a \\
hospital in northwestern \\
Spain in 2001 \\
\end{tabular} & $\begin{array}{l}\text { Medical history, } \\
\text { patient interview }\end{array}$ & $\begin{array}{c}\text { Age: } 60.2(14.6) \text { years } \\
\text { Sex: } 83 \% \text { female } \\
\text { Disease duration: } 11.3 \\
(9.1) \text { years }\end{array}$ & $\begin{array}{r}\text { Exclud } \\
\text { Includi } \\
\text { Including other co }\end{array}$ & $\begin{array}{l}\text { ing anti-TNF: } € 342 \\
\text { g anti-TNF: } € 2019 \\
\text { ncomitant medications }\end{array}$ & : \\
\hline \multicolumn{8}{|c|}{$\begin{array}{l}\text { aData are presented as mean (standard deviation) unless otherwise indicated } \\
\text { bercentages are calculated for the total of the corresponding cost category or subcategory } \\
\text { ACR: American College of Rheumatology, DAS: Disease Activity Score, HAQ: Health Assessment Questionnaire, Hosp. ad. hospital admission, IQR: Interquartile Range, } \\
\text { PWD: Permanent Work Disability, Surg. ad. surgical admission, TNF: Tumor Necrosis Factor, TWD: Temporary Work Disability, Work com: Work Compensation }\end{array}$} \\
\hline
\end{tabular}

Table 3: Studies on the cost of rheumatoid arthritis in Spain.

quality of life but inconsistent effects on the mental component $[17,19]$. Using data from EPISER described above, Loza et al. [17] reported that, after adjusting for several confounders in a multiple linear regression analysis, there was a $\beta$ coefficient of -10.5 points [95\% CI: -17.7 to -3.29] for the physical component score of the SF-12. Surprisingly, the mental component showed a slight but not significant positive effect (a $\beta$ coefficient of 2.22 points [95\% CI: -6.15 to 10.59] for the mental component score of the SF-12) [17]. However, Navarro Sarabia et al., in a random sample of 301 patients selected from 2488 patients from ten participating hospitals throughout Spain, found that all dimensions of QoL, including the mental component, as measured by the SF-36, were significantly reduced in patients with RA compared with the general population, the impact being greater on the physical dimensions and pain [19]. A systematic review of 31 studies from several countries evaluating the impact of RA on QoL using the SF-36 also found a greater negative impact on the physical component than on the mental component [5], supporting the findings from the Spanish studies. A similar deterioration in QoL using the EuroQol 5 Dimensions (EQ-5D) 
was also reported in an observational study of 247 consecutive patients with RA recruited by 14 rheumatologists at outpatient clinics. The mean EuroQol Visual Analog Scale (EQ-VAS) score was 63.1 and the mean utility value was 0.65 ; using the Health Utility Index Mark 3, the mean utility score was 0.75 .14

In two qualitative studies carried out using similar methodologies, patients with RA perceived HRQoL as their ability to do things, and their perception of HRQoL was influenced by sociodemographic variables such as age, education, and economic level $[15,16]$.

\section{Cost of rheumatoid arthritis in spain}

Two studies have analyzed the direct and indirect cost of RA in Spain, and one study evaluated the cost of pharmacologic treatment (Table 3). The two studies analyzing the cost of RA were 12-month observational studies; one was retrospective [18] and the other was prospective [19]. Direct costs included medical (e.g., medical visits, diagnostic tests, drugs, hospital admissions) and nonmedical (e.g., help, transportation) costs; indirect costs were related to work disability. In both studies, direct costs associated with the disease represented the larger economic burden ( $70 \%$ and $75 \%$ of total costs) $[18,19]$. This is similar to findings from an Italian cost-of-illness study, wherein direct costs represented $69 \%$ of the annual costs of RA in 2012 [27]. However, the distribution of direct costs differed: in the retrospective study [18], the greatest contribution was 'nonmedical costs' (60.7\% of direct costs), while in the prospective study [19], these costs represented $19.6 \%$ of direct costs. Total cost per patient per year also differs between the two Spanish studies: this was estimated at \$US10, 419 (2001 values), equivalent to $€ 11,707$, and $€ 3600$ (2002 values), for the retrospective [18] and prospective [19] cohort studies, respectively. In the Italian study, the annual cost per patient was higher, at $€ 13,595$ (2012 values). Unlike the Spanish studies, this Italian study included the cost of productivity of the caregiver (i.e., an annual cost per patient of $€ 1,424$ ) [27].

Although the two Spanish studies may provide useful historical information, they were undertaken more than 10 years ago and do not reflect the current cost of illness in Spain as regards hospitalization rates, type of care, work disability compensation, and drug costs. Importantly, uptake of biologics is now greater than it was 10 years ago, and these treatments contribute considerably to the cost of the disease. For instance, in a study carried out as early as 2001 in 150 consecutive patients recruited from a Spanish hospital, including the cost of etanercept and infliximab treatments increased the annual cost per patient almost six-fold, from $€ 342$ to $€ 2019$ (2001 values) [22]. Therefore, there is a clear need for further investigation of the cost of RA in Spain.

\section{Conclusion}

This review shows that in Spain, RA is associated with deterioration in QoL, increased disability and costs, and, ultimately, an excess mortality. Epidemiologic data on RA in Spain indicate a disease frequency similar to that of other developed countries. Since most studies were carried out several years ago, further research is needed to assess the current situation in Spain, especially with respect to the medical and nonmedical costs associated with the disease.

\section{References}

1. Alamanos $\mathrm{Y}$, Voulgari PV, Drosos AA (2006) Incidence and prevalence of rheumatoid arthritis, based on the 1987 American College of Rheumatology criteria: a systematic review. Semin Arthritis Rheum 36: 182-188.

2. Gullick NJ, Scott DL (2008) Co-morbidities in established rheumatoid arthritis Best Pract Res Clin Rheumatol 25: 469-483.

3. Dadoun S, Zeboulon-Ktorza N, Combescure C, Elhai M, Rozenberg S, et al (2013) Mortality in rheumatoid arthritis over the last fifty years: systematic review and meta-analysis. Joint Bone Spine 80: 29-33.

4. Toledano E, Candelas G, Rosales Z, Martinez Prada C, Leon L, et al. (2012) A meta-analysis of mortality in rheumatic diseases. Reumatol Clin 8: 334-341.

5. Matcham F, Scott IC, Rayner L, Hotopf M, Kingsley GH, et al. (2014) The impact of rheumatoid arthritis on quality-of-life assessed using the SF-36: a systematic review and meta-analysis. Semin Arthritis Rheum 44: 123-130.

6. Sokka T, Kautiainen H, Pincus T, Verstappen SM, Aggarwal A, et al. (2010) Work disability remains a major problem in rheumatoid arthritis in the 2000s: data from 32 countries in the QUEST-RA study. Arthritis Res Ther 12: R42.

7. Lundkvist J, Kastang F, Kobelt G (2008) The burden of rheumatoid arthritis and access to treatment: health burden and costs. Eur J Health Econ 8: S49-S60.

8. Carmona L, Villaverde V, Hernandez-Garcia C, Ballina J, Gabriel R, et al. (2002) The prevalence of rheumatoid arthritis in the general population of Spain. Rheumatology (Oxford) 41: 88-95.

9. Carbonell J, Cobo T, Balsa A, Descalzo MA, Carmona L (2008) The incidence of rheumatoid arthritis in Spain: results from a nationwide primary care registry. Rheumatology (Oxford) 47: 1088-1092.

10. Fina-Aviles F, Medina-Peralta M, Mendez-Boo L, Hermosilla E, Elorza JM, et al. (2016) The descriptive epidemiology of rheumatoid arthritis in Catalonia: a retrospective study using routinely collected data. Clin Rheumatol 35: 751-757.

11. Gonzalez-Gay MA, Gonzalez-Juanatey C, Lopez-Diaz MJ, Pineiro A, GarciaPorrua C, et al. (2007) HLA-DRB1 and persistent chronic inflammation contribute to cardiovascular events and cardiovascular mortality in patients with rheumatoid arthritis. Arthritis Rheum 57: 125-132.

12. Llorca J, Lopez-Diaz MJ, Gonzalez-Juanatey C, Ollier WE, Martin J, et al. (2007) Persistent chronic inflammation contributes to the development of cancer in patients with rheumatoid arthritis from a defined population of northwestern Spain. Semin Arthritis Rheum 37: 31-38.

13. Abásolo L, Judez E, Descalzo MA, Gonzalez-Alvaro I, Jover JA, et al. (2008) Cancer in rheumatoid arthritis: occurrence, mortality, and associated factors in a South European population. Semin Arthritis Rheum 37: 388-397.

14. Carreno A, Fernandez I, Badia X, Varela C, Roset M (2011) Using HAQ-DI to estimate HUI-3 and EQ-5D utility values for patients with rheumatoid arthritis in Spain. Value Health 14: 192-200.

15. Nunez M, Sanchez A, Nunez E, Casals T, Alegre C, et al. (2006) Patients' perceptions of health related quality of life in rheumatoid arthritis and chronic low back pain. Qual Life Res 15: 93-102.

16. Nuñez M, Nuñez E, Sanchez A, del Val JL, Bonet M, et al. (2009) Patients' perceptions of health-related quality of life in rheumatoid arthritis. Clin Rheumatol 28: 1157-1165.

17. Loza E, Abasolo L, Jover JA, Carmona L (2008) Burden of disease across chronic diseases: a health survey that measured prevalence, function, and quality of life. J Rheumatol 35: 159-165.

18. Lajas C, Abasolo L, Bellajdel B, Hernandez-Garcia C, Carmona L, et al. (2003) Costs and predictors of costs in rheumatoid arthritis: a prevalence-based study. Arthritis Rheum 49: 64-70.

19. Navarro Sarabia F, Ballina García FJ, Hernández Cruz B, Hernández Mejía R, Ruiz Montesinos MD, et al. (2004) Costes calidad de vida-artritis reumatoide. Estudio económico y de la calidad de vida de los pacientes con artritis reumatoide en España. Resulta. Rev Esp Reumatol 31: 184-189.

20. Ruiz-Montesinos MD, Hernandez-Cruz B, Ariza-Ariza R, Carmona L, Ballina J, et al. (2005) Cost analysis in a cohort of rheumatoid arthritis patients managed in rheumatology units in Spain. Reumatol Clin 1: 193-199.

21. Maese J, Garcia De Yebenes MJ, Carmona L, Hernandez-Garcia C (2012) 
Citation: Andrade P, Sacristan JA, Rentero ML, Hammen V, Dilla T (2017) The Burden of Rheumatoid Arthritis in Spain. Health Econ Outcome Res Open Access 3: 126. doi: 10.4172/2471-268x/1000126

Page 6 of 6

Management of rheumatoid arthritis in Spain (emAR II). Clinical characteristics of the patients. Reumatol Clin 8: 236-242.

22. Mera Varela A, Blanco J, Caamano M (2003) Aproximation to the cost of pharmacological treatment of rheumatoid arthritis in Spain. An Med Intern 20: 114-121.

23. Sanchez Martinez M, Garcia-Monforte A, Rivera J (2001) Survival study of rheumatoid arthritis patients in Madrid (Spain). A 9-year prospective follow-up. Scand J Rheumatol 30: 195-198.

24. Dougados M, Soubrier M, Antunez A, Balint P, Balsa A, et al. (2014) Prevalence of comorbidities in rheumatoid arthritis and evaluation of their monitoring: results of an international, cross-sectional study (COMORA). Ann Rheum Dis 73: 62-68.

25. Naranjo A, Sokka T, Descalzo MA, Calvo-Alen J, Horslev-Petersen K, et al. (2008) Cardiovascular disease in patients with rheumatoid arthritis: results from the QUEST-RA study. Arthritis Res Ther 10: R30.

26. Liao KP, Solomon DH (2013) Traditional cardiovascular risk factors, inflammation and cardiovascular risk in rheumatoid arthritis. Rheumatology 52 45-52.

27. Turchetti G, Bellelli S, Mosca M (2013) The social cost of rheumatoid arthritis in Italy: the results of an estimation exercise. Reumatismo 65: 271-277. 